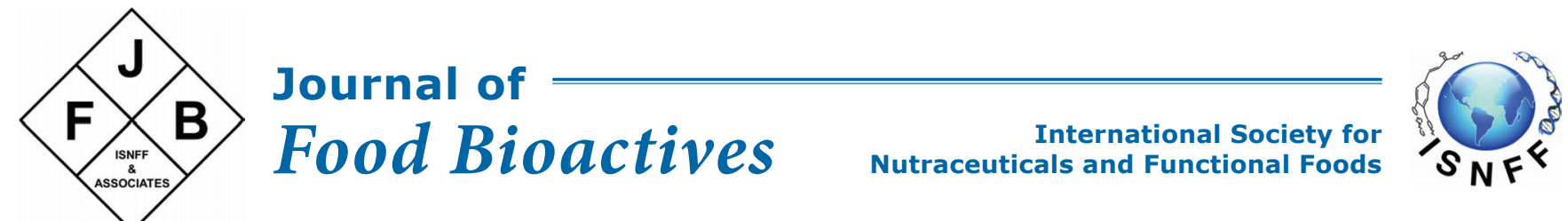

\title{
Edible insects as a source of food bioactives and their potential health effects
}

\author{
Klaus W. Lange* and Yukiko Nakamura
}

Department of Experimental Psychology, University of Regensburg, Regensburg, Germany

*Corresponding author: Klaus W. Lange, Institute of Psychology, University of Regensburg, 93040 Regensburg, Germany. Tel: +49 941 9433815; Fax: +49 941 9434496; E-mail: klaus.lange@ur.de

DOI: $10.31665 /$ JFB.2021.14264

Received: June 22, 2021; Revised received \& accepted: June 29, 2021

Citation: Lange, K.W., and Nakamura, Y. (2021). Edible insects as a source of food bioactives and their potential health effects. J. Food Bioact. 14: 4-9.

\begin{abstract}
Entomophagy (consumption of insects) is an issue of global nutritional and environmental interest. The nutritional value of insects appears to be high, since they are rich in protein and fat and provide a range of vitamins and minerals. Edible insects contain similar amounts of protein to conventional meat and higher levels of polyunsaturated fatty acids. Due to their high content of protein, micronutrients and fiber, insects could become a valuable alternative to food derived from other animals. The findings of various in vitro and in vivo animal studies suggest beneficial effects of entomophagy with respect to cardiovascular, gastrointestinal and non-communicable diseases as well as immune functions and carcinogenesis. Edible insects appear to be a promising and insufficiently explored source of macronutrients, micronutrients and food bioactives. In the course of time, some edible insects may meet the criteria of functional food ingredients. However, there is a significant lack of research investigating health outcomes in humans. The available evidence in humans, derived from randomized controlled trials, suggests a role of edible insects in the promotion of mineral status and the modulation of gut microbiota, with some prebiotic effects. High-quality clinical studies assessing efficacy, oral intake safety and allergy risk are needed.
\end{abstract}

Keywords: Entomophagy; Edible insects; Food bioactives; Functional food; Health promotion.

\section{Introduction}

In the interests of preserving agricultural resources and decreasing the ecological impact of animal food, the consumption of insects (entomophagy) has become an issue of global interest. The farming of insects as a highly nutritious protein source (van Huis et al., 2013) may offer a sustainable means of food production (van Huis and Oonincx, 2017). Entomophagy has been a feature of human diets for millennia and has also played a role in cultural and religious practices (Bodenheimer, 1951; Costa-Neto, 2005). Early accounts suggest that insects were valued foods in ancient Greece and Rome (Bodenheimer, 1951). In contrast to Europe and North America, a wide range of insects, including grasshoppers, beetles, crickets, locusts, ants, termites and caterpillars, are consumed in many regions of Asia, Africa, Latin America and Australia. For ex- ample, more than 100 edible insect species have been documented in Mexico (Ramos Elorduy de Conconi, 1987) and over 1900 worldwide (van Huis et al., 2013; Jongema, 2017). In cultures with a tradition of insect consumption, insects form a regular part of the diet. Insects have been reported to be commonly eaten by more than two billion people worldwide (van Huis et al., 2013). While insects may be most frequently consumed when the availability of other animal foods is limited, some insects are valued as delicacies (Dufour, 1987). Insects can be eaten whole but are today more commonly processed into insect powder, fat and fractions enriched with protein or fiber.

While insects have been extensively studied as a source of bioactive agents for medical purposes (Costa-Neto, 2005), much less is known of their potential to provide food bioactives. The nutritional profile of insects can be highly variable and depends on the insect species, the developmental stage when harvested and 
the plants consumed by the insects (EFSA Scientific Committee, 2015). Other environmental factors influencing their nutritional value include day length, light intensity, temperature and humidity (Finke and Oonincx, 2014). While insects appear to be a valuable source of nutrients such as protein and fat and also of bioactive compounds (e.g. polyunsaturated fatty acids, flavonoids and other unidentified compounds with antioxidative capacity), some species have been found to also contain antinutritional compounds, such as tannins and phytic acid (ANSES, 2015).

The use of edible insects as a food source raises questions involving global food security (van Huis, 2015), consumer acceptance, especially in Western countries (Hartmann and Siegrist, 2017), and efficient commercialization and production of edible insects while preserving wild populations (van Huis et al., 2013). The present perspective will address the feasibility and health effects of insects as a source of food bioactives and micronutrients.

\section{Nutrients and bioactives in edible insects}

\subsection{Protein and amino acids}

Edible insects may provide a valuable source of protein, with the average protein content varying between $35 \%$ in dry matter for termites, $61 \%$ for crickets and grasshoppers and as high as $77 \%$ for some species (Rumpold and Schlüter, 2013). The protein content of insects is generally in the same range as that of beef and pork (40-75 g/100 g dry weight) (Istituto Nazionale della Nutrizione, 1989). However, crude protein content of whole insects with hard exoskeletons, such as grasshoppers, locusts, ants and termites, may not accurately reflect biologically available nitrogen (Dreyer and Wehmeyer, 1982; Dufour, 1987). Protein content of insects is determined primarily by their type of diet and stage of metamorphosis. Insect proteins appear to be highly digestible by humans (Belluco et al., 2013), and the consumption of insects may contribute to the total intake of protein, significantly enhancing nutritional quality in the human diet (Bukkens, 1997). Almost all types of edible insects meet the required content in amino acids (e.g. phenylalanine, tyrosine, tryptophan, threonine and lysine), as recommended by the World Health Organization (2007).

\subsection{Lipids}

The content of total lipids, cholesterol and saturated, unsaturated and polyunsaturated fatty acids in insects is highly dependent on species and developmental stage (Mishyna and Glumac, 2021) as well as diet (van Broekhoven et al., 2015). The total fat content of insects ranges between 2 and $62 \%$ (Williams et al., 2016). The profile of fatty acids in insects is generally similar to that of animal fats and vegetable oils (Tzompa-Sosa and Fogliano, 2017). However, in comparison with beef and pork, insects are particularly rich in unsaturated fatty acids, with some species containing up to 65\% (Rumpold and Schlüter, 2013; Tzompa-Sosa et al., 2014; Yerlikaya et al., 2013; Zielińska et al., 2015). In whole larvae of yellow mealworms, unsaturated fatty acids account for approximately $75 \%$ of total fatty acid content (Tzompa-Sosa et al., 2014). Terrestrial edible insects appear to contain higher amounts of long-chain polyunsaturated fatty acids, in particular omega- 6 fatty acids, than aquatic insects (Fontaneto et al., 2011). The omega-6/omega-3 fatty acid ratio, which has been found to be 1.2-27 in whole insects (Tzompa-Sosa et al., 2014), can be controlled by diet (Lehtovaara et al., 2017). However, the high content of unsaturated fatty acids may be affected by oxidation during the handling and processing of insect products (van Huis et al., 2013).

\subsection{Minerals}

The content of minerals contained in edible insects varies largely between species. In general, insects are low in calcium and potassium. Crickets and locusts have been shown to be rich in magnesium (Rumpold and Schlüter, 2013), and high levels of magnesium, copper and zinc are present in cricket powder (Montowska et al., 2019). The amounts of chemically available calcium, copper, magnesium, manganese and zinc in mealworm (Tenebrio molitor) and grasshopper (Sphenarium purpurascens) have been shown to be higher than in beef (Latunde-Dada et al., 2016). High levels of iron and zinc have been found in crickets and termites (Christensen et al., 2006). Low sodium concentrations allow the inclusion of edible insects in low sodium diets (Rumpold and Schlüter, 2013).

\subsection{Vitamins}

Knowledge concerning the vitamin content of edible insects is limited. Relatively high levels of B complex vitamins (riboflavin, pantothenic acid and biotin) have been found in several species (Rumpold and Schlüter, 2013; Finke and Oonincx, 2014), while vitamin C content seems to be low (Rumpold and Schlüter, 2013). Vitamin B concentrations in grasshoppers (Brachystola magna) have been shown to remain constant across their developmental stages, while the levels of vitamins A, C, D and E increase with development (Zamudio-Flores et al., 2019).

\subsection{Fiber}

Insects contain significant amounts of fiber. The exoskeleton of many insects consists of chitin, a long-chain polymer of $\mathrm{N}$-acetylglucosamine, which accounts for approximately $10 \%$ of dried weight (Belluco et al., 2013; van Huis et al., 2013). Chitin content depends to a large extent on insect species and developmental stage (Finke, 2007). Purified chitin comprises approximately 90\% dietary fiber (Maezaki et al., 1993), and chitin digestion has been demonstrated in humans (Paoletti et al., 2007). Chitin and its deacylated form, chitosan, can be regarded as functional food components potentially providing beneficial effects in wound healing, colonic and cardiovascular health, cholesterol reduction and innate and adaptive immune responses (Lee et al., 2008; Prosky, 2000; Shahidi and Abuzaytoun, 2005; Tripathi and Singh, 2018).

\subsection{Antioxidants}

Some insects have been shown to contain phenolics and flavonoids. Substantial levels of these compounds have been demonstrated in silkworm larval powders, which, due to their antioxidative properties, may have positive health effects (Ji et al., 2017; Oliveira et al., 2014). Furthermore, the flavonoid apigenin has been found in edible stink bugs (Encosternum delegorguei) (Musundire et al., 2014), and saponins have been found in the cricket Henicus whellani (Kunatsa et al., 2020) and the larvae and pupae of silkworms (Omotoso, 2015). Several species of edible insects, including crickets, silkworms and grasshoppers, have been reported to display antioxidant capacities as shown in their water and 
Table 1. Potential health benefits of edible insects

\begin{tabular}{|c|c|}
\hline Effect & Findings \\
\hline \multicolumn{2}{|l|}{ In vitro studies } \\
\hline $\begin{array}{l}\text { Angiotensin converting } \\
\text { enzyme inhibitory } \\
\text { activity relevant to } \\
\text { hypertension treatment }\end{array}$ & $\begin{array}{l}\text { Angiotensin converting enzyme inhibitory activity of peptides from various insect species similar to that } \\
\text { of bioactive compounds from other animals (Cito et al., 2017). Elevated angiotensin converting enzyme } \\
\text { inhibitory activity of hydrolysates following gastrointestinal digestion of various insects (Vercruysse et al., } \\
2005 \text {; Vercruysse et al., 2008; Wu et al., 2011) }\end{array}$ \\
\hline Antioxidant activity & $\begin{array}{l}\text { Antioxidant capacities of water and liposoluble extracts from several insect species 2-3 times higher than } \\
\text { those of orange juice and olive oil (Di Mattia et al., 2019) }\end{array}$ \\
\hline Anticarcinogenic activity & $\begin{array}{l}\text { Potential anticancer activity of various proteins, peptides (Slocinska et al., 2008) and alkaloids (Pettit et al., } \\
\text { 2005) contained in insects as well as of crude insect-derived extracts (Ahn et al., 2000) }\end{array}$ \\
\hline \multicolumn{2}{|l|}{ In vivo studies } \\
\hline Hypolipidemic activity & $\begin{array}{l}\text { Lipid metabolism of rats affected by omega-3 } \alpha \text {-linolenic acid-rich silkworm chrysalis oil, suggesting } \\
\text { improvements of hyperlipidemia and hyperglycemia (Mentang et al., 2011). Reductions in body weight } \\
\text { gain as well as levels of total cholesterol, plasma low-density lipoprotein cholesterol and plasma } \\
\text { triacylglycerol in rats following administration of chitooligosaccharides from chitosan of larvae skin (Clanis } \\
\text { bilineata) (Xia et al., 2013) }\end{array}$ \\
\hline Antiobesity effect & $\begin{array}{l}\text { Attenuation of body weight gain in obese mice fed a high-fat diet following administration of yellow } \\
\text { mealworm larvae powder (Seo et al., 2017). Dose-dependent reduction in body weight gain, organ weight } \\
\text { and adipose tissue volume of mice following administration of Korean horn beetle larvae (Yoon et al., } \\
\text { 2015). Inhibition of lipase activity related to the digestion of dietary lipids following administration of } \\
\text { house cricket and yellow mealworm extracts (Del Navarro Hierro et al., 2020) }\end{array}$ \\
\hline $\begin{array}{l}\text { Anti-hepatic } \\
\text { steatosis activity }\end{array}$ & $\begin{array}{l}\text { Preventive effects of silkworm larval powder regarding hepatic steatosis and injury in ethanol- } \\
\text { treated rats through elevating fatty acid } \beta \text {-oxidation, reducing de novo synthesis of fatty } \\
\text { acids and inhibiting oxidative stress and inflammatory response (Hong et al., 2018) }\end{array}$ \\
\hline Gut microbiota effect & $\begin{array}{l}\text { Support of growth of the probiotic bacterium Bifidobacterium animalis and reduction } \\
\text { in plasma TNF- } \alpha \text { following consumption of whole cricket powder in humans, suggesting } \\
\text { improved gut health and reduced systemic inflammation (Stull et al., 2018) }\end{array}$ \\
\hline Health-span and lifespan & Increased health-span and lifespan of Drosophila fed mature silkworm larval powder (Nguyen et al., 2016) \\
\hline
\end{tabular}

liposoluble extracts, at two or three times higher than those of olive oil or orange juice (Di Mattia et al., 2019).

\section{Future directions}

Edible insects appear to be a source of high-quality protein, micronutrients and other food bioactives (Rumpold and Schlüter, 2013). In addition, insects may provide economic and environmental benefits, since they may be a more sustainable and environmentally friendly source of nutrients than other animals (Halloran et al., 2014; Dobermann et al., 2017; van Huis and Oonincx, 2017). However, generalized statements concerning the nutritional value of insects and the potential health benefits of their consumption may fail to account for the high variability in protein, micronutrients and food bioactive content, which depend on insect species (about 2000), metamorphic stage and feeding style.

A comparative analysis of the nutritional value of insects and red meat found that, in general, the value in regard to protein content, essential amino acids and unsaturated fatty acids was similar (Orkusz, 2021). Due to the significant variance in individual nutrients, the study was unable to draw a definitive conclusion as to whether meat or insects provide greater nutritional value. In comparison with meat, some insect species contain a higher content of protein, fat and polyunsaturated fatty acids as well as of tocopherol, riboflavin, calcium, zinc, copper, and manganese, but lower levels of saturated fatty acids, monounsaturated fatty acids, iron, thiamine and niacin. Furthermore, in contrast to meat, edible insects are also a source of dietary fiber and vitamin C (Orkusz, 2021).

\subsection{Health benefits of edible insects}

A wide variety of potential health benefits in humans consuming edible insects have been suggested (see Table 1). Insects may prevent micronutrient deficiencies and play a role in the management of chronic diseases, such as cardiovascular disease, diabetes and cancer (Nowakowski et al., 2021).

The high concentrations of iron and zinc contained in crickets and termites (Christensen et al., 2006) are of interest, since deficiencies in these minerals are common in low-income countries. Twenty-five percent and $17 \%$ of the world's population have been shown to be at risk of iron and zinc deficiency, respectively (Gibson, 2015; McLean et al., 2009). Anemia due to iron deficiency is present in a quarter of the global population, affecting mainly women and preschool-aged children (McLean et al., 2009). Inadequate intake of zinc can be found in almost a fifth of the world's population (Gibson, 2015) and has been estimated to be responsible for approximately 450,000 deaths annually, mainly in Africa and Asia (Fischer Walker et al., 2009). This has led to the use of edible insects in fortification programs (Bauserman et al., 2015). In a cluster-randomized controlled trial, the efficacy of a cereal made from micronutrient-rich caterpillars on decreasing stunting and anemia in infants was assessed in the Democratic Republic 
of Congo (Bauserman et al., 2015). One hundred and seventy-five 6-month-old infants received either caterpillar cereal daily or their usual diet up until 18 months of age. While supplementation with caterpillar cereal did not decrease the prevalence of stunting in infants at 18 months, hemoglobin levels were significantly higher in the experimental group and the prevalence of anemia was significantly reduced (Bauserman et al., 2015).

Effects of edible insect compounds on metabolic health have been demonstrated in rodent studies. For example, the administration of chitin-chitosan has been shown to decrease fat storage in mice fed a high-fat diet. This compound may have the potential to reduce the risk of type-2 diabetes in humans (Han et al., 1999). Furthermore, larvae powder from mealworm (Tenebrio molitor) and Korean horn beetle (Allomyrina dichotoma) administered to high-fat diet-induced obese mice has been reported to play a role in the regulation of food intake and the inhibition of adipogenesis (Kim et al., 2016; Seo et al., 2017).

Edible insects have also been suggested to be involved in cardiovascular health through their reduction of high blood pressure. Inhibitors of angiotensin-converting enzyme, which causes the constriction of blood vessels, are used as a medication for cardiovascular diseases. Inhibitory angiotensin-converting enzyme activity has been revealed in several insect species, including silkworm, yellow mealworm and wax moth (Cito et al., 2017).

Gut health may be influenced by chitin and other fibers contained in crickets. In a 6-week, double-blind, crossover dietary intervention comprising 20 healthy adults, the effects of consuming $25 \mathrm{~g} / \mathrm{d}$ of whole cricket powder on gut microbiota were evaluated (Stull et al., 2018). Intake of cricket powder was demonstrated to support growth of a probiotic bacterium (Bifidobacterium animalis), which increased 5.7-fold. A decrease in plasma TNF- $\alpha$ was also found. These results suggest that cricket consumption may improve gut health and decrease systemic inflammation.

Edible insect species possess a large reservoir of antimicrobial peptides, which may serve as alternatives to available antibiotics (Tonk and Vilcinskas, 2017). This calls for further investigation, especially in view of the threat of multidrug-resistant pathogens. However, potential adverse effects of such peptides, including allergenicity, immunogenicity and cytotoxicity, also need to be explored. Chitin has been demonstrated to be capable of enhancing immune functions (Mack et al., 2015; van Dyken and Locksley, 2018). Moreover, chitin content has been associated with the beneficial effects of mealworm (Tenebrio molitor) and super mealworm (Zophobas morio) larvae prebiotics in reducing E. coli and Salmonella infections in broiler chickens (Islam and Yang, 2017).

Environmental conditions and feed play important roles in the nutrient and bioactive content of edible insects. Suboptimal levels of these compounds can be improved by, for example, adding a source of omega-3 fatty acids such as flaxseed to the insects' diet in order to influence the omega-6/omega- 3 fatty acid ratio (Oonincx et al., 2020). Furthermore, low ultraviolet irradiation has been shown to elevate vitamin D concentrations in yellow mealworms and house crickets (Oonincx et al., 2018).

It is important to note that the available findings regarding healthrelated effects of entomophagy are based mainly on in vitro and in vivo animal studies. There is currently a significant lack of relevant studies assessing health outcomes in humans (Stull, 2021). Further evidence based on high-quality randomized clinical trials is therefore needed.

\subsection{Adverse effects}

Possible food safety hazards related to edible insects have been reported (van der Fels-Klerx et al., 2018). For example, the intake of African silkworm (Anaphe venata) larvae may be involved in the etiology of a seasonal ataxic syndrome (Adamolekun, 1993; Adamolekun and Ibikunle, 1994). Due to the taxonomic proximity of insects to house dust mites, cross reactivity of individuals with house dust mite allergy may occur. Moreover, biological and chemical contaminants should be considered. In yellow mealworms and black soldier flies, bioaccumulation of arsenic and lead, respectively, has been observed (Schrögel and Wätjen, 2019). Contamination of locusts with pesticides could potentially cause adverse health effects in those ingesting these insects (Saeed et al., 1993). The consumption of edible insect species has been suggested to be generally no more hazardous than that of other animal products (Mézes, 2018). In recent years, massive ground and air spraying campaigns have been launched to fight locust plagues in several East African countries (McConnell, 2021). Broad spectrum pesticides render insects inedible and may have other significant adverse impacts on human health and environment.

\section{Conclusion}

A wide range of edible insects are suitable for human consumption. As a form of mini-livestock, insects have attracted increasing interest among food scientists, economists and environmentalists, due to their potential as a valuable source of nutrition and their lesser environmental footprint when compared to the production of red meat.

In many respects, the nutritional value of edible insects has been found to be equivalent or even superior to that of other animalbased foods. Based on the findings of in vitro and in vivo animal studies, potential health-promoting effects of insect consumption for the cardiovascular system, the gastrointestinal tract, metabolic problems, such as obesity and type- 2 diabetes, immune functions and carcinogenesis have been suggested. However, there is a significant dearth of studies evaluating health outcomes in humans following the intake of insects. The findings of a small number of well-designed randomized trials in humans suggest that consumption of certain insects may enhance health by compensating for deficiencies in micronutrients or promoting gut health.

Edible insects appear to be a promising and insufficiently explored source of macronutrients, micronutrients and food bioactives, which may be able to provide a wide range of food supplements and functional food ingredients for specific purposes. However, in view of the very large number of edible insect species and the many factors affecting their nutrient and bioactive content, generalizable conclusions concerning their nutritional value and potential health-promoting properties cannot be drawn. Scientifically rigorous and well-controlled human intervention trials are needed to confirm health benefits and assess entomophagy-related risks.

\section{References}

Adamolekun, B. (1993). Anaphe venata entomophagy and seasonal ataxic syndrome in southwest Nigeria. Lancet 341(8845): 629.

Adamolekun, B., and Ibikunle, F.R. (1994). Investigation of an epidemic of seasonal ataxia in Ikare, western Nigeria. Acta Neurol. Scand. 90(5): 309-311.

Ahn, M.Y., Ryu, K.S., Lee, Y.W., and Kim, Y.S. (2000). Cytotoxicity and Lamino acid oxidase activity of crude insect drugs. Arch. Pharm. Res. 23(5): 477-481.

ANSES. (2015). OPINION of the French Agency for Food, Environmental 
and Occupational Health \& Safety. https://www.anses.fr/en/system/ files/BIORISK2014sa0153EN.pdf.

Bauserman, M., Lokangaka, A., Gado, J., Close, K., Wallace, D., Kodondi, K.-K., Tshefu, A., and Bose, C. (2015). A cluster-randomized trial determining the efficacy of caterpillar cereal as a locally available and sustainable complementary food to prevent stunting and anaemia. Public Health Nutr. 18(10): 1785-1792.

Belluco, S., Losasso, C., Maggioletti, M., Alonzi, C.C., Paoletti, M.G., and Ricci, A. (2013). Edible insects in a food safety and nutritional perspective: a critical review. Compr. Rev. Food Sci. Food Saf. 12(3): 296-313.

Bodenheimer, F.S. (1951). Insects as human food: A chapter of the ecology of man. Springer, Dordrecht.

Bukkens, S.G. (1997). The nutritional value of edible insects. Ecol. Food Nutr. 36(2-4): 287-319.

Christensen, D.L., Orech, F.O., Mungai, M.N., Larsen, T., Friis, H., and Aagaard-Hansen, J. (2006). Entomophagy among the Luo of Kenya: a potential mineral source? Int. J. Food Sci. Nutr. 57(3-4): 198-203.

Cito, A., Botta, M., Francardi, V., and Dreassi, E. (2017). Insects as source of angiotensin converting enzyme inhibitory peptides. J. Insects Food Feed 3(4): 231-240.

Costa-Neto, E.M. (2005). Entomotherapy, or the medicinal use of insects. J. Ethnobiol. 25(1): 93-114.

Del Navarro Hierro, J., Gutiérrez-Docio, A., Otero, P., Reglero, G., and Martin, D. (2020). Characterization, antioxidant activity, and inhibitory effect on pancreatic lipase of extracts from the edible insects Acheta domesticus and Tenebrio molitor. Food Chem. 309: 125742.

Di Mattia, C., Battista, N., Sacchetti, G., and Serafini, M. (2019). Antioxidant activities in vitro of water and liposoluble extracts obtained by different species of edible insects and invertebrates. Front. Nutr. 6: 106.

Dobermann, D., Swift, J.A., and Field, L.M. (2017). Opportunities and hurdles of edible insects for food and feed. Nutr. Bull. 42(4): 293-308.

Dreyer, J.J., and Wehmeyer, A.S. (1982). Nutritive value of Mopanie worms. S. Afr. J. Sci. 78: 33-35.

Dufour, D.L. (1987). Insects as food: a cse study from the Northwest Amazon. Am. Anthropol. 89(2): 383-397.

EFSA Scientific Committee. (2015). Risk profile related to production and consumption of insects as food and feed. EFSA Journal 13(10): 4257.

Finke, M.D. (2007). Estimate of chitin in raw whole insects. Zoo Biol. 26(2) 105-115.

Finke, M.D., and Oonincx, D. (2014). Insects as food for insectivores. In: Shapiro-Ilan Morales-Ramos, J., Rojas, G., and Shapiro-Ilan, D.I. (Ed.) Mass Production of Beneficial Organisms: Invertebrates and Entomopathogens. Elsevier, pp. 583-616.

Fischer Walker, C.L., Ezzati, M., and Black, R.E. (2009). Global and regional child mortality and burden of disease attributable to zinc deficiency. Eur. J. Clin. Nutr. 63(5): 591-597.

Fontaneto, D., Tommaseo-Ponzetta, M., Galli, C., Risé, P., Glew, R.H., and Paoletti, M.G. (2011). Differences in fatty acid composition between aquatic and terrestrial insects used as food in human nutrition. Ecol. Food Nutr. 50(4): 351-367.

Gibson, R.S. (2015). Dietary-induced zinc deficiency in low income countries. Nutr. Today 50(1): 49-55.

Halloran, A., Muenke, C., Vantomme, P., and van Huis, A. (2014). Insects in the human food chain: global status and opportunities. Food Chain 4(2): 103-118

Han, L.K., Kimura, Y., and Okuda, H. (1999). Reduction in fat storage during chitin-chitosan treatment in mice fed a high-fat diet. Int. J. Obes. Relat. Metab. Disord. 23(2): 174-179.

Hartmann, C., and Siegrist, M. (2017). Insects as food: Perception and acceptance. Findings from current research. Ernahrungs-Umschau 64(3): 44-50.

Hong, K.-S., Yun, S.-M., Cho, J.-M., Lee, D.-Y., Ji, S.-D., Son, J.-G., and Kim E.-H. (2018). Silkworm (Bombyx mori ) powder supplementation alleviates alcoholic fatty liver disease in rats. J. Funct. Foods 43: 29-36.

Islam, M.M., and Yang, C.-J. (2017). Efficacy of mealworm and super mealworm larvae probiotics as an alternative to antibiotics challenged orally with Salmonella and E. coli infection in broiler chicks. Poult. Sci. 96(1): 27-34.

Istituto Nazionale della Nutrizione (INN). (1989). Tabelle di Composizione degli Alimenti. INN, Rome.

Ji, S.-D., Nguyen, P., Yoon, S.-M., Kim, K.-Y., Son, J.G., Kweon, H., and Koh, Y.H. (2017). Comparison of nutrient compositions and pharmacological effects of steamed and freeze-dried mature silkworm powders generated by four silkworm varieties. J. Asia Pac. Entomol. 20: 1410-1418.

Jongema, Y. (2017). List of edible insects of the world. https://www.wur. nl/en/Research-Results/Chairgroups/Plant-Sciences/Laboratory-ofEntomology/Edible-insects/Worldwide-species-list.htm.

Kim, J., Yun, E.-Y., Park, S.-W., Goo, T.-W., and Seo, M. (2016). Allomyrina dichotoma larvae regulate food intake and body weight in high fat diet-induced obese mice through mTOR and Mapk signaling pathways. Nutrients 8(2): 100.

Kunatsa, Y., Chidewe, C., and Zvidzai, C.J. (2020). Phytochemical and antinutrient composite from selected marginalized Zimbabwean edible insects and vegetables. J. Agric. Food Res. 2: 100027

Latunde-Dada, G.O., Yang, W., and Vera Aviles, M. (2016). In vitro iron availability from insects and sirloin beef. J. Agric. Food Chem. 64(44): 8420-8424.

Lee, C.G., Da Silva, C.A., Lee, J.-Y., Hartl, D., and Elias, J.A. (2008). Chitin regulation of immune responses: an old molecule with new roles. Curr. Opin. Immunol. 20(6): 684-689.

Lehtovaara, V.J., Valtonen, A., Sorjonen, J., Hiltunen, M., Rutaro, K., Malinga, G.M., Nyeko, P., and Roininen, H. (2017). The fatty acid contents of the edible grasshopper Ruspolia differens can be manipulated using artificial diets. J. Insects Food Feed 3(4): 253-262.

Mack, I., Hector, A., Ballbach, M., Kohlhäufl, J., Fuchs, K.J., Weber, A., Mall, M.A., and Hartl, D. (2015). The role of chitin, chitinases, and chitinase-like proteins in pediatric lung diseases. Mol. Cell. Pediatr. 2(1): 3 .

Maezaki, Y., Yamazaki, A., Mizuochi, K., and Tsuji, K. (1993). Measurement of dietary fiber in chitin and chitosan by the enzymatic-gravimetric method. J. Agricult. Chem. Soc. Japan 67(4): 677-684.

McConnell, T. (2021). A locust plague hit East Africa. The pesticide solution may have dire consequences. National Geographic, March 24, 2021. https://www.nationalgeographic.com/environment/article/locustplague-hit-east-africa-pesticide-solution-may-have-dire-consequences.

McLean, E., Cogswell, M., Egli, I., Wojdyla, D., and Benoist, B.d.e. (2009). Worldwide prevalence of anaemia, WHO Vitamin and Mineral Nutrition Information System, 1993-2005. Public Health Nutr. 12(4): 444-454.

Mentang, F., Maita, M., Ushio, H., and Ohshima, T. (2011). Efficacy of silkworm (Bombyx mori L.) chrysalis oil as a lipid source in adult Wistar rats. Food Chem. 127(3): 899-904.

Mézes, M. (2018). Food safety aspect of insects: A review. Acta Alimentaria 47(4): 513-522.

Mishyna, M., and Glumac, M. (2021). So different, yet so alike Pancrustacea: Health benefits of insects and shrimps. J. Funct. Foods 76: 104316.

Montowska, M., Kowalczewski, P.Ł., Rybicka, I., and Fornal, E. (2019). Nutritional value, protein and peptide composition of edible cricket powders. Food Chem. 289: 130-138.

Musundire, R., Zvidzai, J.C., and Chidewe, C. (2014). Bio-active compounds composition in edible stinkbugs consumed in South-Eastern districts of Zimbabwe. Int. J. Biol. 6(3): 36-45.

Nguyen, P., Kim, K.-Y., Kim, A.-Y., Kim, N.-S., Kweon, H., Ji, S.-D., and Koh, Y.H. (2016). Increased healthspan and resistance to Parkinson's disease in Drosophila by boiled and freeze-dried mature silk worm larval powder. J. Asia Pac. Entomol. 19(2): 551-561.

Nowakowski, A.C., Miller, A.C., Miller, M.E., Xiao, H., and Wu, X. (2021). Potential health benefits of edible insects. Crit. Rev. Food Sci. Nutr. $1-10$.

De Oliveira, L.L., De Carvalho, M.V., and Melo, L. (2014). Health promoting and sensory properties of phenolic compounds in food. Rev. Ceres 61(Suppl.): 764-779.

Omotoso, O.T. (2015). An evaluation of the nutrients and some anti-nutrients in silkworm Bombyxmori L. (Bombycidae Lepidoptera). Jordan J. Biol. Sci. 8(1): 45-50.

Oonincx, D.G.A.B., Laurent, S., Veenenbos, M.E., and van Loon, J.J.A. (2020). Dietary enrichment of edible insects with omega 3 fatty acids. Insect Sci. 27(3): 500-509. 
Oonincx, D.G.A.B., van Keulen, P., Finke, M.D., Baines, F.M., Vermeulen M., and Bosch, G. (2018). Evidence of vitamin D synthesis in insects exposed to UVb light. Sci. Rep. 8(1): 10807.

Orkusz, A. (2021). Edible insects versus meat-nutritional comparison: knowledge of their composition is the key to good health. Nutrients 13(4): 1207.

Paoletti, M.G., Norberto, L., Damini, R., and Musumeci, S. (2007). Human gastric juice contains chitinase that can degrade chitin. Ann. Nutr. Metab. 51(3): 244-251.

Pettit, G.R., Meng, Y., Herald, D.L., Knight, J.C., and Day, J.F. (2005). Antineoplastic agents. 553. The Texas grasshopper Brachystola magna. J. Nat. Prod. 68(8): 1256-1258.

Prosky, L. (2000). When is dietary fiber considered a functional food? Biofactors 12(1-4): 289-297.

Ramos Elorduy de Conconi, J. (1987). Los insectos: Como fuente de proteínas en el futuro. Segunda editión. Editorial Limusa, México.

Rumpold, B.A., and Schlüter, O.K. (2013). Nutritional composition and safety aspects of edible insects. Mol. Nutr. Food Res. 57(5): 802-823.

Saeed, T., Dagga, F.A., and Saraf, M. (1993). Analysis of residual pesticides present in edible locusts captured in Kuwait. Arab. Gulf J. Sci. Res. 11(1): 1-5.

Schrögel, P., and Wätjen, W. (2019). Insects for food and feed-safety aspects related to mycotoxins and metals. Foods 8(8): 288

Seo, M., Goo, T.-W., Chung, M.Y., Baek, M., Hwang, J.-S., Kim, M.-A., and Yun, E.-Y. (2017). Tenebrio molitor larvae inhibit adipogenesis through AMPK and MAPKs signaling in 3T3-L1 adipocytes and obesity in high-fat diet-induced obese mice. Int. J. Mol. Sci. 18(3): 518.

Shahidi, F., and Abuzaytoun, R. (2005). Chitin, chitosan, and co-products: chemistry, production, applications, and health effects. Adv. Food Nutr. Res. 49: 93-135.

Slocinska, M., Marciniak, P., and Rosinski, G. (2008). Insects antiviral and anticancer peptides: new leads for the future? Protein Pept. Lett. 15(6): 578-585.

Stull, V.J. (2021). Impacts of insect consumption on human health. J. Insects Food Feed 1-20.

Stull, V.J., Finer, E., Bergmans, R.S., Febvre, H.P., Longhurst, C., Manter D.K., Patz, J.A., and Weir, T.L. (2018). Impact of edible cricket consumption on gut microbiota in healthy adults, a double-blind, randomized crossover trial. Sci. Rep. 8(1): 10762.

Tonk, M., and Vilcinskas, A. (2017). The medical potential of antimicrobial peptides from insects. Curr. Top. Med. Chem. 17(5): 554-575.

Tripathi, K., and Singh, A. (2018). Chitin, chitosan and their pharmacological activities: a review. Int. J. Pharm. Sci. Res. 9(7): 2626-2635.

Tzompa-Sosa, D.A., and Fogliano, V. (2017). Potential of Insect-Derived Ingredients for Food Applications. In: Shields, V.D. (Ed.). Insect Physiology and Ecology. InTech.

Tzompa-Sosa, D.A., Yi, L., van Valenberg, H.J., van Boekel, M.A., and Lakemond, C.M. (2014). Insect lipid profile: aqueous versus organic solvent-based extraction methods. Food Res. Int. 62: 1087-1094.

van Broekhoven, S., Oonincx, D.G.A.B., van Huis, A., and van Loon, J.J.A. (2015). Growth performance and feed conversion efficiency of three edible mealworm species (Coleoptera: Tenebrionidae) on diets composed of organic by-products. J. Insect Physiol. 73: 1-10.

van der Fels-Klerx, H.J., Camenzuli, L., Belluco, S., Meijer, N., and Ricci, A. (2018). Food safety issues related to uses of insects for feeds and foods. Compr. Rev. Food Sci. Food Saf. 17(5): 1172-1183.

van Dyken, S.J., and Locksley, R.M. (2018). Chitins and chitinase activity in airway diseases. J. Allergy Clin. Immunol. 142(2): 364-369.

van Huis, A. (2015). Edible insects contributing to food security? Agric \& Food Secur 4(1): 1-9.

van Huis, A., and Oonincx, D.G.A.B. (2017). The environmental sustainability of insects as food and feed. A review. Agron. Sustain. Dev. 37(5): 43.

van Huis, A., van Itterbeeck, J., Klunder, H., Mertens, E., Halloran, A., Muir, G., and Vantomme, P. (2013). Edible insects: Future prospects for food and feed security. FAO Forestry Paper 171. Rome, Italy: Food and Agriculture Organization of the United Nations.

Vercruysse, L., Smagghe, G., Herregods, G., and van Camp, J. (2005). ACE inhibitory activity in enzymatic hydrolysates of insect protein. J. Agric. Food Chem. 53(13): 5207-5211.

Vercruysse, L., Smagghe, G., Matsui, T., and van Camp, J. (2008). Purification and identification of an angiotensin I converting enzyme (ACE) inhibitory peptide from the gastrointestinal hydrolysate of the cotton leafworm, Spodoptera littoralis. Process Biochem. 43(8): 900-904.

Williams, J.P., Williams, J.R., Kirabo, A., Chester, D., and Peterson, M. (2016). Nutrient content and health benefits of insects. In: Dossey, A.T., Morales-Ramos, J., and Guadalupe Rojas, M. (Ed.). Insects as Sustainable Food Ingredients. Elsevier, pp. 61-84.

World Health Organization. (2007). Protein and amino acid requirements in human nutrition: Report of a joint WHO/FAO/UNU expert consultation. WHO technical report series 935. World Health Organization, Geneva.

Wu, Q.-Y., Jia, J.-Q., Tan, G.-X., Xu, J.-L., and Gui, Z.-Z. (2011). Physicochemical properties of silkworm larvae protein isolate and gastrointestinal hydrolysate bioactivities. Afr. J. Biotechnol. 10(32): 6145-6153.

Xia, Z., Chen, J., and Wu, S. (2013). Hypolipidemic activity of the chitooligosaccharides from Clanis bilineata (Lepidoptera), an edible insect. Int. J. Biol. Macromol. 59: 96-98.

Yerlikaya, P., Topuz, O.K., Buyukbenli, H.A., and Gokoglu, N. (2013). Fatty acid profiles of different shrimp species: effects of depth of catching. J. Aquat. Food Prod. Technol. 22(3): 290-297.

Yoon, Y.-I., Chung, M.Y., Hwang, J.-S., Han, M.S., Goo, T.-W., and Yun, E.Y. (2015). Allomyrina dichotoma (Arthropoda: Insecta) larvae confer resistance to obesity in mice fed a high-fat diet. Nutrients $7(3)$ : 1978-1991.

Zamudio-Flores, P.B., -Gonzaléz, M.H., and Cano, V.G.-G. (2019). Food supplements from a Grasshopper: A developmental stage-wise evaluation of amino acid profile, protein and vitamins in Brachystola magna (Girard). Emir. J. Food Agric. 31(7): 561-568.

Zielińska, E., Baraniak, B., Karaś, M., Rybczyńska, K., and Jakubczyk, A. (2015). Selected species of edible insects as a source of nutrient composition. Food Res. Int. 77: 460-466. 